Article

\title{
Parafiniukite, $\mathrm{Ca}_{2} \mathrm{Mn}_{3}\left(\mathrm{PO}_{4}\right)_{3} \mathrm{Cl}$, a New Member of the Apatite Supergroup from the Szklary Pegmatite, Lower Silesia, Poland: Description and Crystal Structure
}

\author{
Adam Pieczka ${ }^{1, *}\left(\mathbb{0}\right.$, Cristian Biagioni ${ }^{2}$, Bożena Gołębiowska $^{1}\left(\mathbb{0}\right.$, Piotr Jeleń $^{3}$, Marco Pasero ${ }^{2}$ \\ and Maciej Sitarz ${ }^{3}$ \\ 1 Department of Mineralogy, Petrography and Geochemistry, AGH University of Science and Technology, \\ 30-059 Kraków, Poland; goleb@agh.edu.pl \\ 2 Dipartimento di Scienze Della Terra, Università di Pisa, Via Santa Maria 53, I-56126 Pisa, Italy; \\ cristian.biagioni@unipi.it (C.B.); marco.pasero@unipi.it (M.P.) \\ 3 Faculty of Materials Science and Ceramics, AGH University of Science and Technology, \\ 30-059 Kraków, Poland; pjelen@agh.edu.pl (P.J.); msitarz@agh.edu.pl (M.S.) \\ * Correspondence: pieczka@agh.edu.pl
}

Received: 29 September 2018; Accepted: 22 October 2018; Published: 26 October 2018

\begin{abstract}
Parafiniukite, ideally $\mathrm{Ca}_{2} \mathrm{Mn}_{3}\left(\mathrm{PO}_{4}\right)_{3} \mathrm{Cl}$, is a new apatite-supergroup mineral from the Szklary pegmatite, Lower Silesia, Poland. It occurs as anhedral grains, up to $250 \mu \mathrm{m}$ in size, dark olive green in colour, embedded in a mixture of Mn-oxides and smectites around beusite. It has a vitreous luster, and it is brittle with irregular, uneven fracture. The calculated density is $3.614 \mathrm{~g} \cdot \mathrm{cm}^{-3}$. Parafiniukite is hexagonal, space group $P 6_{3} / m$, with unit-cell parameters $a=9.4900(6), c=6.4777(5) \AA$, $V=505.22(5) \AA^{3}, Z=2$. The eight strongest reflections in the calculated $\mathrm{X}$-ray powder diffraction pattern of parafiniukite are [ $d$ in $\AA$ (I) $h k l]$ : 3.239 (39) 002; 2.801 (55) 211; 2.801 (76) 121; 2.740 (100) 300; 2.675 (50) 112; 2.544 (69) 202; 1.914 (31) 222; and 1.864 (22) 132. Chemical analysis by an electron microprobe gave (in wt\%) $\mathrm{P}_{2} \mathrm{O}_{5} 39.20, \mathrm{MgO} 0.19, \mathrm{CaO} 24.14, \mathrm{MnO} 31.19, \mathrm{FeO} 2.95, \mathrm{Na}_{2} \mathrm{O}$ 0.05, F 0.39, $\mathrm{Cl} 3.13, \mathrm{H}_{2} \mathrm{O}_{\text {(calc) }} 0.68, \mathrm{O}=(\mathrm{Cl}, \mathrm{F})-0.87$, sum 101.05. The resulting empirical formula on the basis of 13 anions per formula unit is $\left(\mathrm{Mn}_{2.39} \mathrm{Ca}_{2.34} \mathrm{Fe}_{0.22} \mathrm{Mg}_{0.03} \mathrm{Na}_{0.01}\right)_{\Sigma 4.99} \mathrm{P}_{3.00} \mathrm{O}_{12}\left[\mathrm{Cl}_{0.48}(\mathrm{OH})_{0.41} \mathrm{~F}_{0.11}\right]$. The crystal structure of parafiniukite was refined to an $R_{1}=0.0463$ for 320 independent reflections with $F_{\mathrm{o}}>4 \sigma\left(F_{\mathrm{o}}\right)$ and 41 refined parameters. Parafiniukite is isotypic with apatites. Manganese is the dominant cation at the $M(2)$ site, and $\mathrm{Ca}$ is the dominant cation at the $M(1)$ site.
\end{abstract}

Keywords: parafiniukite; apatite supergroup; hedyphane group; manganese; calcium; phosphorus; Szklary pegmatite; Lower Silesia; Poland

\section{Introduction}

Parafiniukite, ideally $\mathrm{Ca}_{2} \mathrm{Mn}_{3}\left(\mathrm{PO}_{4}\right)_{3} \mathrm{Cl}$, was discovered in an LCT (Li-Cs-Ta) granitic pegmatite hosted by serpentinites of the Szklary massif, Lower Silesia, SW Poland. The mineral occurs as small relict grains, not exceeding $250 \mu \mathrm{m}$ in size, embedded in a Mn-oxide, smectite mixture overgrowing partly altered beusite, the most frequent mineral component of phosphate aggregates occurring in graphic zone of the pegmatite. The new mineral and its name have been approved by the Commission on New Minerals, Nomenclature and Classification (CNMNC) of the International Mineralogical Association (IMA 2018-047). The name of the mineral is after Jan Parafiniuk (b. 1954), Professor of mineralogy at the Institute of Geochemistry, Mineralogy and Petrology of the University of Warsaw, Poland. The parafiniukite holotype (specimen Sz 31) is deposited in the collection of the Mineralogical 
Museum of the University of Wrocław, Faculty of Earth Science and Environmental Management, Institute of Geological Sciences, 50-205 Wrocław, Cybulskiego 30, Poland, with the catalogue number MMWr IV8024. The crystal used for the collection of single-crystal data is deposited in the mineralogical collection of the Museo di Storia Naturale, Università di Pisa, Via Roma 79, Calci (Pisa), Italy, catalogue number 19902. Parafiniukite was previously reported as "Mn-rich apatite" [1], and codified by the IMA Subcommittee on Unnamed Minerals as UM2007-18:PO:CaClMn mineral, $\mathrm{Mn}_{3} \mathrm{Ca}_{2}\left(\mathrm{PO}_{4}\right)_{3}(\mathrm{Cl}, \mathrm{F}, \mathrm{OH})$, corresponding to the $\mathrm{Mn}$-dominant analogue of apatite. The present study indicates that the correct end-member formula of this mineral is $\mathrm{Ca}_{2} \mathrm{Mn}_{3}\left(\mathrm{PO}_{4}\right)_{3} \mathrm{Cl}$. The aim of this paper is to describe this member of the apatite supergroup.

\section{Occurrence}

Parafiniukite, was discovered in the Szklary LCT (Li-Cs-Ta) pegmatite $\left(50^{\circ} 39.068^{\prime} \mathrm{N}, 16^{\circ} 49.932^{\prime} \mathrm{E}\right)$, $\sim 6 \mathrm{~km}$ N of the Zabkowice Śląkie town, $\sim 60 \mathrm{~km}$ south of Wrocław, in Lower Silesia, SW Poland, outcropped in the northern part of the Szklary serpentinite massif. The massif is considered as a part of the tectonically dismembered Central-Sudetic Ophiolite. It adjoins the Góry Sowie Block (GSB) unit on the east and is enclosed as a mega-boudin in the mylonitized Góry Sowie gneisses of the Early Carboniferous Niemcza Shear Zone. The Szklary pegmatite, now completely excavated by mineral collectors, formed a NNE-SSW elongated lens or a boudin $\sim 4 \times 1 \mathrm{~m}$ large in planar section, which was in primary intrusive contact with an altered aplitic gneiss, up to $2 \mathrm{~m}$ thick, to the southwest, and both rocks were surrounded by tectonized serpentinite. A vermiculite-chlorite-talc zone was locally present along the pegmatite-serpentinite contact (for more information about the geological setting of the pegmatite see [2]). The pegmatite represents the beryl-columbite-phosphate subtype of the rare element (REL)-Li pegmatite class sensu Černý and Ercit [3]. The age of the pegmatite, estimated at $383 \pm 2 \mathrm{Ma}$ (CHIME dating on monazite-(Ce) [4]), is significantly older than the age $\sim 335-340 \mathrm{Ma}$ of the neighbouring small late-syntectonic dioritic, syenitic and granodioritic intrusions occurring in the Niemcza Shear Zone (e.g., [5]). It is rather contemporaneous with the anatectic event in the adjacent GSB [6-8]. The Szklary pegmatite is built mostly of sodic plagioclase (oligoclase-albite), microcline perthite, quartz and biotite, with minor $\mathrm{Fe}^{3+}$-bearing schorl-dravite tourmaline, spessartine garnet and muscovite. It is relatively poorly zoned with: (1) a marginal graphic zone of albite + quartz \pm minor-to-accessory biotite commonly altered to clinochlore + black tourmaline; (2) a coarser-grained intermediate graphic zone of microcline perthite + quartz + small quartz-tourmaline nests, with smaller amounts of albite and biotite and, simultaneously, increased abundance of muscovite and spessartine; accessory chrysoberyl is locally present in muscovite aggregates; (3) a central zone of graphic microcline + quartz, in places developed as blocky microcline with interstitial albite, rare muscovite, and no black tourmaline or biotite [4,9]. The zones (2) and (3) contain numerous accessory minerals disseminated as inclusions mainly in quartz, microcline, albite, and muscovite. They include native elements and alloys (arsenic, antimony, bismuth, gold, stibarsen, and paradocrasite), $\mathrm{Nb}-\mathrm{Ta}$ oxides (columbite-group minerals, stibiocolumbite and stibiotantalite, fersmite, pyrochlore-, microlite- and betafite-group minerals), Mn-oxides (ernienickelite, jianshuiite, cesàrolite, cryptomelane, and others), As and $\mathrm{Sb}$ oxides, lepageite (type locality, TL) and other arsenites and antimonites, beryllium minerals (chrysoberyl, beryl, and bertrandite), phosphate and arsenate minerals (monazite-(Ce), cheralite, xenotime-( $(Y)$, Mn-bearing fluor-, hydroxyl- and chlorapatite, pieczkaite, parafiniukite, beusite and beusite-( $\mathrm{Ca})$, bobfergusonite, fillowite, lithiophilite grading to sicklerite, simferite and purpurite, natrophilite, $\mathrm{Pb}$ - and Ba-bearing dickinsonite, triploidite, fairfieldite, phosphohedyphane, plumbogummite, mitridatite, pararobertsite, gorceixite, arsenogorceixite), and a number of silicates, such as e.g., (Be,Mn, $\mathrm{Na}, \mathrm{Cs}$ )-bearing cordierite, tourmaline-supergroup minerals (dravite/schorl and foitite/oxy-schorl), dumortierite-supergroup minerals (dumortierite, holtite, nioboholtite (TL), titanoholtite (TL) and szklaryite (TL)), spessartine, zircon, harmotome and pollucite [4,10-12].

Parafiniukite is closely associated with small aggregates of beusite, up to $\sim 1 \mathrm{~cm}$ in size, which underwent intense alteration into a secondary assemblage of Mn-oxides and smectites. 
Pieczkaite and rarer parafiniukite usually survived only as small relicts, not exceeding $250 \mu \mathrm{m}$ in size, surrounded by the mixture (Figure 1).

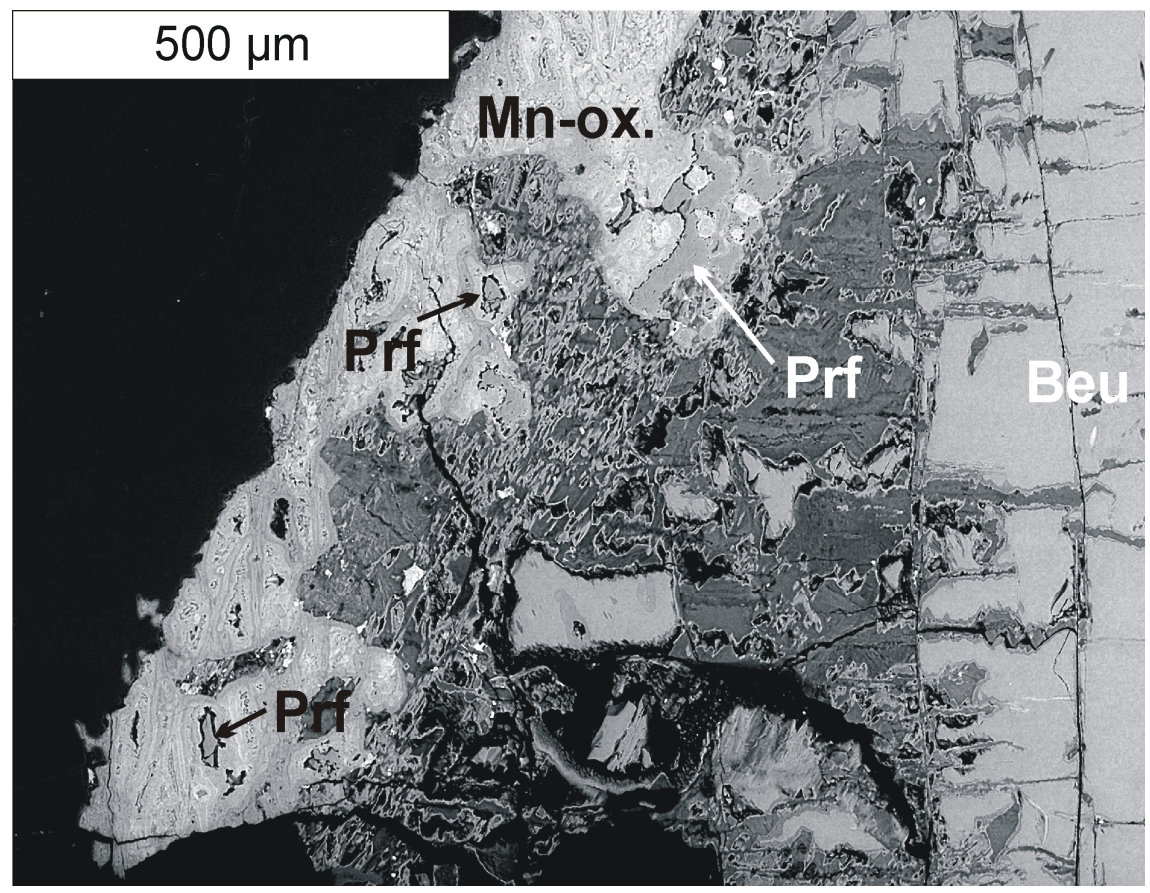

Figure 1. Parafiniukite as relict grains within the Mn-oxide; smectite matrix, around beusite. Holotype specimen MMWrIV8024. Labels: Beu = beusite; Mn-ox. = Mn-oxides; Prf = parafiniukite.

\section{Experimental Data}

\subsection{Mineral Description and Physical Properties}

Parafiniukite occurs only as small anhedral grains, up to $250 \mu \mathrm{m}$ in size (Figure 1). The mineral is transparent with dark olive-green colour sometimes masked by the Mn-oxides. It has a vitreous luster, and it is brittle with irregular, uneven fracture. No forms and twinning were observed. Due to the very small amount of available material and its possible contamination by the surrounding Mn-oxides, streak, hardness, density as well as main optical properties were not determined. Cleavage, parting, and fluorescence were not observed. By analogy with pieczkaite [13], the Mohs hardness of parafiniukite could be estimated at $4-5$. The density calculated on the basis of the empirical formula and the refined unit-cell volume of type parafiniukite is $3.614 \mathrm{~g} \cdot \mathrm{cm}^{-3}$. The mean refractive index, obtained from the Gladstone-Dale relation $[14,15]$, using the empirical formula and calculated density, is 1.731 .

\subsection{Chemical Data}

Preliminary EDS chemical analysis showed $\mathrm{Ca}, \mathrm{Mn}, \mathrm{P}$, and $\mathrm{Cl}$ as the only elements with $Z>8$. Quantitative chemical analyses were carried out using a Cameca SX 100 electron microprobe (WDS mode, $15 \mathrm{kV}, 20 \mathrm{nA}, 3 \mu \mathrm{m}$ beam diameter) at the Inter-Institute Analytical Complex for Minerals and Synthetic Substances at the University of Warsaw. Standard materials (element, emission line) were: fluorophlogopite $(\mathrm{F} K \alpha), \mathrm{YbPO}_{4}(\mathrm{P} K \alpha)$, hematite $(\mathrm{Fe} K \alpha)$, rhodonite $(\mathrm{Mn} K \alpha)$, diopside $(\mathrm{Mg} K \alpha$, Si $K \alpha, \mathrm{Ca} K \alpha)$, albite $(\mathrm{Na} K \alpha)$, tugtupite $(\mathrm{Cl} K \alpha)$, orthoclase $(\mathrm{Al} K \alpha, \mathrm{K} K \alpha)$, celestine $(\mathrm{Sr} L \alpha)$, baryte $(\mathrm{S} K \alpha, \mathrm{Ba} L \alpha)$, crocoite $(\mathrm{Pb} M \alpha)$ and sphalerite $(\mathrm{Zn} K \alpha)$ and $\mathrm{GaAs}(\mathrm{As} L \alpha)$. The following diffracting crystals were used: PC0 for F; TAP for $\mathrm{Na}, \mathrm{Mg}$, Al, Si and As; LPET for P, S, Cl, K, Ca, Sr and Pb; LLIF for Mn, Fe, Zn and Ba. Aluminium, Si, S, K, Zn, Sr, As, Ba and Pb were sought but found below the detection limits. The raw data were reduced with the PAP routine [16]. Direct $\mathrm{H}_{2} \mathrm{O}$ determination 
was not performed owing to scarcity of material. However, the occurrence of $\mathrm{H}_{2} \mathrm{O}$ was confirmed by micro-Raman spectroscopy (see below). The analytical data on the holotype material are given in Table 1.

Table 1. Chemical composition of parafiunikite (in $w \mathrm{t} \%$ ).

\begin{tabular}{cccc}
\hline Constituent & Mean $(\boldsymbol{n}=\mathbf{1 0})$ & Range & e.s.d. \\
\hline $\mathrm{P}_{2} \mathrm{O}_{5}$ & 39.20 & $38.98-39.44$ & 0.14 \\
$\mathrm{MgO}$ & 0.19 & $0.12-0.27$ & 0.05 \\
$\mathrm{CaO}$ & 24.14 & $23.66-24.64$ & 0.39 \\
$\mathrm{MnO}$ & 31.19 & $30.04-31.78$ & 0.62 \\
$\mathrm{FeO}$ & 2.95 & $2.72-3.15$ & 0.16 \\
$\mathrm{Na}_{2} \mathrm{O}$ & 0.05 & $0.01-0.07$ & 0.02 \\
$\mathrm{~F}$ & 0.39 & $0.29-0.46$ & 0.05 \\
$\mathrm{Cl}$ & 3.13 & $3.00-3.29$ & 0.09 \\
$\mathrm{H}_{2} \mathrm{O}_{(\text {calc })}$ & 0.68 & $0.61-0.71$ & 0.03 \\
$\mathrm{O}=(\mathrm{F}+\mathrm{Cl})$ & -0.87 & & \\
Total & 101.05 & & \\
\hline
\end{tabular}

Note: $\mathrm{H}_{2} \mathrm{O}$ was calculated according to stoichiometry, in order to have $1(\mathrm{OH}+\mathrm{F}+\mathrm{Cl})$ per formula unit (pfu); e.s.d., estimated standard deviation.

The empirical formula of parafiniukite (with rounding errors) calculated in relation to $12 \mathrm{O}^{2-}$ and 1 $(\mathrm{F}, \mathrm{Cl}, \mathrm{OH})^{-}$anion per formula unit (apfu) is $\left(\mathrm{Mn}_{2.39} \mathrm{Ca}_{2.34} \mathrm{Fe}_{0.22} \mathrm{Mg}_{0.03} \mathrm{Na}_{0.01}\right)_{\Sigma 4.99} \mathrm{P}_{3.00} \mathrm{O}_{12}\left[\mathrm{Cl}_{0.48}(\mathrm{OH})_{0.41} \mathrm{~F}_{0.11}\right]$. Taking into account the results of the crystal-structure investigation (see below), the ideal formula of parafiniukite should be written as $\mathrm{Ca}_{2} \mathrm{Mn}_{3}\left(\mathrm{PO}_{4}\right)_{3} \mathrm{Cl}$, corresponding to (in wt\%): $\mathrm{P}_{2} \mathrm{O}_{5} 37.14, \mathrm{CaO} 19.56$, $\mathrm{MnO} 37.12, \mathrm{Cl} 6.18$, sum 100.00 .

\subsection{Micro-Raman Spectroscopy}

The unpolarized micro-Raman spectra in the range $100-4000 \mathrm{~cm}^{-1}$ (Figure 2) were collected on a polished sample of parafiniukite with randomly oriented crystals in nearly back-scattered geometry at the Faculty of Materials Science and Ceramics, AGH UST, Cracow, Poland, using a Horiba Labram integrated with an Olympus BX40 confocal microscope with a $100 \times$ objective. The $532 \mathrm{~nm}$ line of a solid-state Nd-YAG laser $(10 \mathrm{~mW})$ was used. The minimum lateral and depth resolution was set to $\sim 1 \mu \mathrm{m}$. The system was calibrated using the $520.7 \mathrm{~cm}^{-1}$ Raman band of silicon. The spectra were collected through two acquisitions with single counting times of $600 \mathrm{~s}$. The backscattered radiation was analyzed with an $1800 \mathrm{~mm}^{-1}$ grating monochromator.

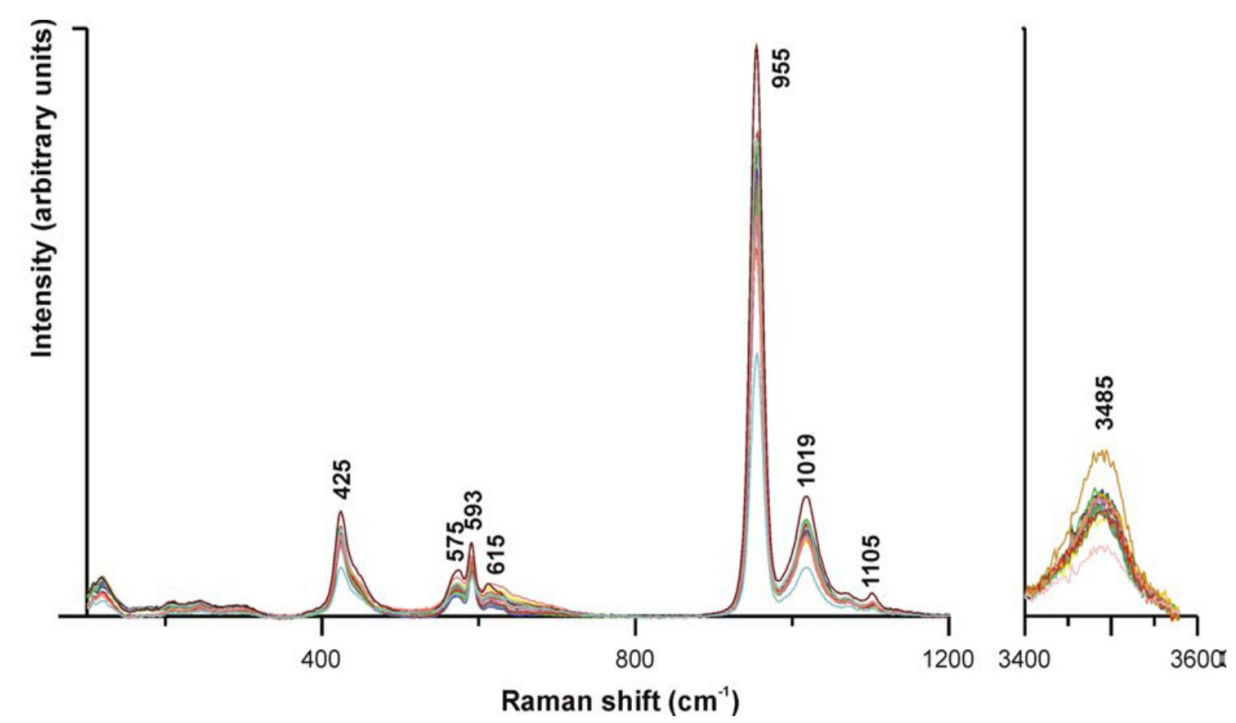

Figure 2. Raman spectra of parafiniukite in the spectral ranges $100-1200 \mathrm{~cm}^{-1}$ and $3400-3600 \mathrm{~cm}^{-1}$. 
In Figure 2, the Raman spectra are shown, as recorded in various relicts of the holotype parafiniukite. The bands at $\sim 955$ (strong), 1019 (medium) and 1105 (weak) $\mathrm{cm}^{-1}$ may be assigned to stretching vibrations of the $\mathrm{PO}_{4}$ groups, in agreement with [13]. The peaks at $\sim 615$ (weak), 593 (medium), 575 (medium) and $425 \mathrm{~cm}^{-1}$ (medium) are due to the bending vibrations of $\mathrm{PO}_{4}$ groups. The weaker peaks below $\sim 300 \mathrm{~cm}^{-1}$ are due to deformations of the Ca and Mn polyhedra, whereas the peak at $\sim 3485 \mathrm{~cm}^{-1}$ is from stretching vibrations of $\mathrm{O}-\mathrm{H}$ bonds.

\subsection{Crystallography}

A crystal fragment $(70 \times 40 \times 30 \mu \mathrm{m})$ was extracted from polished section Sz31 and mounted on a carbon fibre. Intensity data were collected using a Bruker Smart Breeze diffractometer $(50 \mathrm{kV}$, $30 \mathrm{~mA}$ ) equipped with an air-cooled CCD detector, and graphite-monochromatized Mo K $\alpha$ radiation. The detector-to-crystal working distance was $50 \mathrm{~mm}$. A total of 1418 frames was collected in $\omega$ and $\varphi$ scan modes. The exposure time was $120 \mathrm{~s}$ per frame. The data were integrated and corrected for Lorentz and polarization, background effects, and absorption using the package of software Apex3 [17], resulting in a set of 422 independent reflections (see Supplementary Materials). The refinement of unit-cell parameters constrained to hexagonal symmetry gave $a=9.4900(6), c=6.4777(5) \AA$, $V=505.22(5) \AA^{3}$. The $c: a$ ratio calculated from the unit-cell parameters is 0.6826 . The statistical tests on the distribution of $|E|$ values $\left(\left|E^{2}-1\right|=0.784\right)$ suggested an acentric structure; taking into account also the systematic absences, the space group $P 6_{3}$ could be proposed. However, any trial to refine the structure in that space group symmetry was not successful and the space group $\mathrm{P}_{3} / \mathrm{m}$ was eventually chosen. The crystal structure was refined starting from the atomic coordinates of turneaureite [18] using Shelxl-2014 [19]. Scattering curves for neutral atoms were taken from the International Tables for Crystallography [20]. The site occupancy factors (s.o.f.) of the three cation sites were initially refined using the following scattering curves: Ca vs. $M n$ at the $M(1)$ and $M(2)$ sites, and $\mathrm{P}$ vs. $\square$ (vacancy) at the T site. The three $\mathrm{O}$ sites $(\mathrm{O}(1), \mathrm{O}(2)$, and $\mathrm{O}(3))$ were refined assuming the full occupancy of $\mathrm{O}$. Owing to the complex chemistry of parafiniukite, the position of the $\mathrm{X}$ anions was found through successive difference-Fourier maps, showing the occurrence of an electron density maximum at $(0,0,1 / 4)$. The site scattering of this position was refined using the curves of $\mathrm{Cl}$ vs. $\square$. After several cycles of isotropic refinement, the R1 index converged to 0.092. The s.o.f. at M(1) and $\mathrm{M}(2)$ sites showed mixed $(\mathrm{Ca}, \mathrm{Mn})$ occupancies, whereas the $\mathrm{T}$ site was found to be fully occupied by $\mathrm{P}$ only. Its s.o.f. was then fixed to 1 .

After the introduction of the anisotropic displacement parameters for cations, the $R_{1}$ value converged to 0.067 . Assuming an anisotropic model also for the $\mathrm{O}(1), \mathrm{O}(2)$, and $\mathrm{O}(3)$ positions, the $R_{1}$ value converged to 0.056 . However, the anisotropic displacement parameter of $\mathrm{O}(2)$ was negatively defined. The displacement parameter of the $X$ anion was refined isotropically, as discussed in [18]. A residual of $\sim 2.5 e / \AA^{3}$ at $(0,0,0.1667)$ was found. By adding this additional position (named $\left.X b\right)$, constraining the isotropic $U$ value of $X \mathrm{a}$ and $X \mathrm{~b}$ to be equal and the sum of their s.o.f. to be 1 , the $R_{1}$ value converged to 0.058 . Finally, we tried to refine the anisotropic displacement parameters of $\mathrm{O}(2)$, resulting in positive defined values. The $\mathrm{Xb}$ position was assumed to be occupied by $\mathrm{Cl}$ only, owing to the longer $M(2)-\mathrm{Xb}$ distance, whereas $\mathrm{Xa}$ was assumed to have a mixed $(\mathrm{OH}, \mathrm{F}, \mathrm{Cl})$ occupancy. The site occupancies at the $X$ sub-positions were fixed, taking into account the observed site scattering and the electron microprobe data, to $\left(\mathrm{OH}_{0.40} \mathrm{Cl}_{0.30} \mathrm{~F}_{0.10}\right)$ and $\mathrm{Cl}_{0.20}$ at $\mathrm{Xa}$ and $\mathrm{Xb}$, respectively.

The refinement converged to $R_{1}=0.0463$ for 320 unique reflections with $F_{\mathrm{o}}>4 \sigma\left(F_{\mathrm{o}}\right)(0.0676$ for all 422 reflections) and 41 refined parameters. The chemical formula derived from the structure refinement (SREF) is $\left(\mathrm{Ca}_{2.56} \mathrm{Mn}_{2.44}\right)\left(\mathrm{PO}_{4}\right)_{3}\left[\mathrm{Cl}_{0.50}(\mathrm{OH})_{0.40} \mathrm{~F}_{0.10}\right]$. The details of data collection and refinement are given in Table 2. 
Table 2. Crystal and experimental details for parafiniukite.

\begin{tabular}{|c|c|}
\hline \multicolumn{2}{|c|}{ Crystal Data } \\
\hline Crystal size (mm) & $0.07 \times 0.04 \times 0.03$ \\
\hline Cell setting, space group & Hexagonal, $\mathrm{P}_{3} / \mathrm{m}$ \\
\hline$a(\AA)$ & $9.4900(6)$ \\
\hline$c(\AA)$ & $6.4777(5)$ \\
\hline$V\left(\AA^{3}\right)$ & $505.22(5)$ \\
\hline Z & 2 \\
\hline \multicolumn{2}{|c|}{ Data Collection and Refinement } \\
\hline Radiation, wavelength $(\AA)$ & Mo $K \alpha, \lambda=0.71073$ \\
\hline Temperature $(\mathrm{K})$ & 293 \\
\hline $2 \theta_{\max }\left({ }^{\circ}\right)$ & 54.89 \\
\hline Measured reflections & 6047 \\
\hline Unique reflections & 422 \\
\hline Reflections with $F_{\mathrm{o}}>4 \sigma\left(F_{\mathrm{o}}\right)$ & 320 \\
\hline$R_{\text {int }}$ & 0.1008 \\
\hline$R \sigma$ & 0.0422 \\
\hline Range of $h, k, l$ & $-12 \leq h \leq 12,-12 \leq k \leq 12,-8 \leq l \leq 8$ \\
\hline$R\left[F_{\mathrm{o}}>4 \sigma\left(F_{\mathrm{o}}\right)\right]$ & $\begin{array}{ll}- & 0.0463 \\
- & -\end{array}$ \\
\hline$R$ (all data) & 0.0676 \\
\hline$w R\left(\right.$ on $\left.F_{\mathrm{o}}^{2}\right)$ & 0.0933 \\
\hline Goof & 1.163 \\
\hline Number of least-squares parameters & 41 \\
\hline Maximum and minimum residual peak $\left(e \AA^{-3}\right)$ & $\begin{array}{l}0.77(\text { at } 0.98 \AA \text { from } X \mathrm{~b}) \\
-0.80(\text { at } 0.76 \AA \text { from } T)\end{array}$ \\
\hline
\end{tabular}

The fractional atom coordinates and isotropic or equivalent isotropic displacement parameters are reported in Table 3. Table 4 reports the selected bond distances, whereas Tables 5 and 6 show the proposed site populations and the bond-valence calculations obtained using the bond-valence parameters of Brese and O'Keeffe [21].

Table 3. Site labels, Wyckoff positions, atom coordinates, and equivalent isotropic or isotropic $\left.{ }^{*}\right)$ displacement parameters $\left(\AA^{2}\right)$ for parafiniukite.

\begin{tabular}{cccccc}
\hline Site & Wyckoff & $x / a$ & $y / b$ & $z / c$ & $\boldsymbol{U}_{\text {eq }}$ \\
\hline$M(1)$ & $4 f$ & $2 / 3$ & $1 / 3$ & $0.0054(3)$ & $0.0082(5)$ \\
$M(2)$ & $6 h$ & $0.0177(2)$ & $0.2645(2)$ & $1 / 4$ & $0.0206(5)$ \\
$T$ & $6 h$ & $0.3752(2)$ & $0.4034(2)$ & $1 / 4$ & $0.0103(6)$ \\
$\mathrm{O}(1)$ & $6 h$ & $0.5008(7)$ & $0.3465(6)$ & $1 / 4$ & $0.0119(13)$ \\
$\mathrm{O}(2)$ & $6 h$ & $0.4621(7)$ & $0.5920(7)$ & $1 / 4$ & $0.0247(18)$ \\
$\mathrm{O}(3)$ & $12 i$ & $0.2629(5)$ & $0.3424(5)$ & $0.4403(7)$ & $0.0199(12)$ \\
$\mathrm{Xa}$ & $2 a$ & 0 & 0 & $1 / 4$ & $0.0132(17)^{*}$ \\
$\mathrm{Xb}$ & $4 e$ & 0 & 0 & $0.186(4)$ & $0.0132(17)^{*}$ \\
\hline
\end{tabular}

Table 4. Selected bond lengths (in $\AA$ ) for parafiniukite.

\begin{tabular}{|c|c|c|c|c|c|c|c|c|}
\hline$M(1)$ & $\begin{array}{l}-\mathrm{O}(1) \\
-\mathrm{O}(2) \\
-\mathrm{O}(3)\end{array}$ & $\begin{array}{l}2.280(4) \times 3 \\
2.366(4) \times 3 \\
2.835(4) \times 3\end{array}$ & $M(2)$ & $\begin{array}{l}-\mathrm{O}(3) \\
-\mathrm{O}(2) \\
-\mathrm{O}(3) \\
-\mathrm{Xa} \\
-\mathrm{Xb} \\
-\mathrm{O}(1)\end{array}$ & $\begin{array}{c}2.204(5) \times 2 \\
2.259(6) \\
2.401(4) \times 2 \\
2.431(2) \\
2.466(4) \\
3.070(6)\end{array}$ & $T$ & $\begin{array}{l}-\mathrm{O}(1) \\
-\mathrm{O}(3) \\
-\mathrm{O}(2)\end{array}$ & $\begin{array}{c}1.535(6) \\
1.540(5) \times 2 \\
1.552(6)\end{array}$ \\
\hline
\end{tabular}


Table 5. Refined site scattering vs. calculated site scattering (in electrons) and proposed site occupancy for $M$ sites in parafiniukite.

\begin{tabular}{cccc}
\hline Site & Refined Site Scattering & Proposed Site Population & Calculated Site Scattering \\
\hline$M(1)$ & 43.4 & $\mathrm{Ca}_{1.25} \mathrm{Mn}^{\mathrm{a}}{ }_{0.74} \mathrm{Na}_{0.01}$ & 43.6 \\
$M(2)$ & 69.0 & $\mathrm{Mn}^{\mathrm{a}}{ }_{1.90} \mathrm{Ca}_{1.06} \mathrm{Mg}_{0.04}$ & 69.2 \\
\hline \multicolumn{4}{c}{}
\end{tabular}

Table 6. Bond-valence sums (in valence unit) in parafiniukite.

\begin{tabular}{ccccc}
\hline Site & $\boldsymbol{M ( 1 )}$ & $\boldsymbol{M ( 2 )}$ & $\boldsymbol{T}$ & $\boldsymbol{\Sigma}$ Anions \\
\hline $\mathrm{O}(1)$ & $2 \times \rightarrow 0.37 \downarrow \times 3$ & 0.04 & 1.21 & 1.99 \\
$\mathrm{O}(2)$ & $2 \times \rightarrow 0.29 \downarrow \times 3$ & 0.34 & 1.15 & 2.07 \\
$\mathrm{O}(3)$ & $0.08^{\downarrow \times 3}$ & $0.40^{\downarrow} \times 2$ & $1.19 \downarrow \times 2$ & 1.90 \\
$\mathrm{Xa}$ & & $0.23 \downarrow \times 2$ & & 0.78 \\
$\mathrm{Xb}$ & & $3 \times \rightarrow 0.26$ & & 0.24 \\
$\Sigma$ Cations & 2.22 & 1.98 & 4.74 & \\
\hline
\end{tabular}

Note: In mixed or partially occupied sites, the BVS has been weighted taking into account the site occupancy.

Owing to the small crystal size, powder X-ray diffraction data were not collected. Table 7 reports the X-ray powder diffraction data (for $\mathrm{Cu} K \alpha$ ) calculated on the basis of the refined structural model.

Table 7. Calculated X-ray powder diffraction data $\left(d\right.$ in $\AA$ ) for parafiniukite. Intensity and $d_{\mathrm{hkl}}$ were calculated using the software PowderCell 2.3 [22] on the basis of the structural model given in Table 3. Only reflections with $I_{\text {calc }}>5$ are listed, if not observed. The eight strongest reflections are given in bold.

\begin{tabular}{|c|c|c|c|c|c|}
\hline$I_{\text {calc }}$ & $d_{\text {calc }}$ & $h k l$ & $I_{\text {calc }}$ & $d_{\text {calc }}$ & $h k l$ \\
\hline 13 & 8.22 & 100 & 10 & 2.150 & 311 \\
\hline 7 & 5.09 & 101 & 6 & 1.965 & 113 \\
\hline 6 & 4.109 & 200 & 31 & 1.914 & 222 \\
\hline 16 & 3.470 & 201 & 8 & 1.885 & 320 \\
\hline 39 & 3.239 & 002 & 22 & 1.864 & 132 \\
\hline 14 & 3.106 & 120 & 6 & 1.864 & 312 \\
\hline 16 & 3.013 & 102 & 15 & 1.810 & 321 \\
\hline 55 & 2.801 & 211 & 13 & 1.793 & 140 \\
\hline 76 & 2.801 & 121 & 17 & 1.773 & 123 \\
\hline 100 & 2.740 & 300 & 16 & 1.773 & 213 \\
\hline 50 & 2.675 & 112 & 17 & 1.735 & 402 \\
\hline 69 & 2.544 & 202 & 14 & 1.629 & 232 \\
\hline 7 & 2.523 & 301 & 17 & 1.619 & 004 \\
\hline 13 & 2.279 & 310 & 12 & 1.466 & 502 \\
\hline 10 & 2.242 & 122 & 7 & 1.439 & 151 \\
\hline
\end{tabular}

\section{Discussion}

\subsection{Crystal Structure Description}

The crystal structure of parafiniukite is topologically similar to those of the other members of the apatite supergroup (e.g., [23]). The refined site scattering values, as given in Table 5, agree with the chemical formula calculated from the electron microprobe data. The $M(1)$ and $M(2)$ sites are Ca- and Mn-dominant, respectively, whereas $\mathrm{Cl}$ is the dominant $X$ anion. Hence, the end-member composition of parafiniukite is $\mathrm{Ca}_{2} \mathrm{Mn}_{3}\left(\mathrm{PO}_{4}\right)_{3} \mathrm{Cl}$. A strong partitioning of $\mathrm{Mn}^{2+}$ at the $\mathrm{M}(2)$ site was previously reported in pieczkaite, ideally $\mathrm{Mn}_{5}\left(\mathrm{PO}_{4}\right)_{3} \mathrm{Cl}[13]$.

The $T$ site is occupied by tetrahedrally-coordinated $\mathrm{P}^{5+}$ with distances ranging between 1.535 and $1.556 \AA$. 
The nine-fold coordinated $M(1)$ site has a mixed (Ca,Mn) occupancy. This occupancy can be idealized as $\mathrm{Ca}_{0.625} \mathrm{Mn}_{0.375}$. Taking into account the ionic radii of ${ }^{\left[{ }^{[9]}\right.} \mathrm{Ca}^{2+}(1.18 \AA),{ }^{[9]} \mathrm{Mn}^{2+}(1.04 \AA)$, and ${ }^{[3]} \mathrm{O}^{2-}=1.36 \AA$ (after [13,24]), a $<M(1)-\mathrm{O}>$ distance of $2.49 \AA$ can be predicted, in agreement with the observed $<M(1)-\mathrm{O}>$ distance, i.e., $2.494 \AA$. This average value is slightly larger than that observed in pieczkaite (2.473 $\AA$ ), where the $M(1)$ site is Mn-dominant, with a site occupancy $\mathrm{Mn}_{0.575} \mathrm{Ca}_{0.425}$ [13], and smaller $<M(1)-\mathrm{O}>$ distance than in Ca-apatites, e.g., hydroxylapatite (2.55 $\AA$ [25]).

The $M(2)$ site has a seven-fold coordination and a mixed $(\mathrm{Mn}, \mathrm{Ca})$ occupancy. The site occupancy at $M(2)$ may be idealized as $\mathrm{Mn}_{0.63} \mathrm{Ca}_{0.37}$, to be compared with that reported in pieczkaite, $\mathrm{Mn}_{0.82} \mathrm{Ca}_{0.18}$ [13]. The lower $\mathrm{Mn} /(\mathrm{Mn}+\mathrm{Ca})$ atomic ratio in parafiniukite results in slightly longer $M(2)-\mathrm{O}$ bond distances. $M(2)$ is coordinated also by the monovalent anions at the $X$ site. In parafiunikite, two sub-sites, labelled $X \mathrm{a}$ and $X \mathrm{~b}$, were located; the former on the mirror plane, at $z=1 / 4$, and the latter slightly displaced from the mirror plane. In pieczkaite, the $X$ anion $\left(X=\mathrm{Cl}_{0.62} \mathrm{OH}_{0.38}\right)$ is only slightly displaced from the mirror plane at $z=1 / 4$. Since parafiniukite is a ternary apatite, containing also minor $\mathrm{F}$, the situation is more complicated. Indeed, in order to avoid short anion-anion contacts, only some configurations are possible, confirming that local order within individual [001] anion columns should be present (e.g., $[18,26])$. In parafiniukite, the anion columns are occupied by $\left(\mathrm{Cl}_{0.50} \mathrm{OH}_{0.40} \mathrm{~F}_{0.10}\right)$.

According to previous studies $[27,28], \mathrm{Mn}$ tends to order at the $M(1)$ site. However, as discussed above and observed in pieczkaite [13], Mn is more strongly ordered at the $M(2)$ site than at $M(1)$, with $\mathrm{Mn} /(\mathrm{Mn}+\mathrm{Ca})$ atomic ratios of 0.375 and 0.63 at $M(1)$ and $M(2)$, respectively, to be compared with 0.575 and 0.82 in pieczkaite [13]. This preferential distribution seems to be favoured by the occurrence of $\mathrm{Cl}$ anion at the $X$ site, whereas Mn tends to be ordered at $M(1)$ when $X=F$, indicating that the nature of the monovalent anion strongly affects the ordering of $\mathrm{Mn}$ and $\mathrm{Ca}$ in mixed Ca-Mn apatites [13].

Following [13], the hypothetical short-range ordered distributions could be proposed. The $M(2)$ site population can be simplified as $\mathrm{Mn}_{1.9} \mathrm{Ca}_{1.1}$. All Ca must be locally associated with an $\mathrm{OH}$ group and $F$ at the neighbouring $X$ sites. In the crystal structure of parafiniukite, there is $0.50(\mathrm{OH}+\mathrm{F})$ at $\mathrm{X}$, and this is associated with $0.50 \times 3=1.50 \mathrm{M}(2)$ cations. This means that $\mathrm{OH}$ and $\mathrm{F}$ are bonded to 1.10 $\mathrm{Ca}+0.40 \mathrm{Mn}$, and all $\mathrm{Cl}$ is bonded to $\mathrm{Mn}$.

Parafiniukite corresponds to the end-member composition $\mathrm{Ca}_{2} \mathrm{Mn}_{3}\left(\mathrm{PO}_{4}\right)_{3} \mathrm{Cl}$ hypothesized by Tait et al. [13]. It belongs to class "08.BN Phosphates with only large cations, $\left(\mathrm{OH}\right.$, etc.): $\mathrm{RO}_{4}=0.33: 1$ " in the Strunz-Nickel classification [29] and to the class "41.08 Anhydrous Phosphates, etc. containing hydroxyl or halogen where $(\mathrm{A})_{5}\left(\mathrm{XO}_{4}\right)_{3} \mathrm{Zq}, 41.08 .01$ Apatite group" of the Dana classification [30]. Following [31], parafiniukite is a new member of the Hedyphane Group in the Apatite Supergroup.

\subsection{Crystallization of Parafiniukite}

Parafiniukite is a primary phosphate mineral that crystallized from a highly fractionated melt. The Mn-Fe fractionation index, expressed as $\mathrm{Mn} /(\mathrm{Mn}+\mathrm{Fe})$ atomic ratio, indicates beusite + beusite- $(\mathrm{Ca})$ as the earliest crystallized phosphates $(\mathrm{Mn} /(\mathrm{Mn}+\mathrm{Fe})=0.71-0.92)$, followed by pieczkaite (0.89-0.96), parafiniukite (0.91-0.95), Mn-bearing chlorapatite (0.95-0.99), and $\mathrm{Cl}$-free, $(\mathrm{Mn}, \mathrm{OH})$-bearing fluorapatite (0.97-0.99), determining the position of parafiniukite in the crystallization sequence of apatite-supergroup minerals in the Szklary pegmatite. Szuszkiewicz et al. [2] noticed that this crystallization sequence is reversed in relation to that observed in the Cross-Lake pegmatite, the type locality for pieczkaite [13], where early crystallized manganoan fluorapatite is succeeded by late Mn-rich chlorapatite and pieczkaite. The latter sequence reflects progressive enrichment in $\mathrm{Mn}$ and F, and next also in $\mathrm{Cl}$ with progress in crystallization, corresponding to the general observation that the $\mathrm{Cl}$-enrichment in the apatite structure is typically characteristic of late to secondary stages of evolution (e.g., [32]). Studies of the ( $\mathrm{Mn}, \mathrm{Cl})$-rich apatites from the Szklary pegmatite [2] showed that, contrary to the Cross Lake pieczkaite, they are primary magmatic phases that formed together or slightly after beusites, and their crystallization predates manganoan fluor- to hydroxylapatites. Therefore, the early crystallization of pieczkaite and parafiniukite in the Szklary pegmatite was probably constrained by 
another process, which may be related to the interaction of the evolved pegmatite-forming melt with the ultramafic wall-rock (serpentinite), and its contamination by serpentinite-related fluid-mobile elements, particularly $\mathrm{Cl}$ [33]. This enabled precipitation of the small-volume droplets of a hydrous melt extremely enriched in $\mathrm{Mn}, \mathrm{Cl}$ and $\mathrm{P}$, as a precursor for beusites, pieczkaite and parafiniukite, immixing with normal aluminosilicate melt from which Mn-rich fluorapatite to hydroxylapatite devoid of $\mathrm{Cl}$ crystallized in the final stages of the pegmatite formation. Metasomatic interaction between the Szklary pegmatite and the host serpentinite is also marked by intensive $\mathrm{Mg}$ contamination, appeared by the occurrence of dravite, and the enrichment of the pegmatite in some other rare components like As and $\mathrm{Sb}$ (native elements and alloys, oxides, arsenites and antimonites, arsenates, As- and Sb-bearing dumortierite-supergroup minerals) [11,12], Pb (pyrochlore-, microlite- and betafite group minerals), Bi (native element, pyrochlore-, microlite and betafite group minerals), Ba (K-feldspars, harmotome, baryte), Li and Cs (some phosphates, (Mn,Be,Na,Cs)-bearing cordierite, (Cs,Mg)-bearing beryl, (Cs,Mg)-bearing muscovite, Cs-bearing phlogophite and Cs-bearing annite) identified as serpentinite-related fluid-mobile elements [33], playing important role in zones (1) and (2).

Supplementary Materials: The following are available online at http:/ /www.mdpi.com/2075-163X/8/11/485/ s1, CIF: parafiniukite.

Author Contributions: A.P. found parafiniukite and made its microprobe studies; B.G., P.J. and M.S. performed micro-Raman spectroscopic studies of the mineral, and C.B. and M.P. collected single-crystal X-ray diffraction data and refined the crystal structure; A.P. and C.B. prepared the manuscript.

Funding: This study was supported by the National Science Centre (Poland) grant 2015/17/B/ST10/03231 to A.P.

Conflicts of Interest: The authors declare no conflict of interest.

\section{References}

1. Pieczka, A. Beusite and unusual Mn-rich apatite from the Szklary granitic pegmatite, Lower Silesia, Poland. Can. Mineral. 2007, 45, 901-914. [CrossRef]

2. Szuszkiewicz, A.; Pieczka, A.; Gołębiowska, B.; Dumańska-Słowik, M.; Marszałek, M.; Szełęg, E. Chemical composition of Mn- and Cl-rich apatites from the Szklary pegmatite, Central Sudetes, SW Poland: Taxonomic and genetic implications. Minerals 2018, 8, 350. [CrossRef]

3. Černý, P.; Ercit, T.S. The classification of granitic pegmatites revisited. Can. Mineral. 2005, 43, $2005-2026$. [CrossRef]

4. Pieczka, A.; Szuszkiewicz, A.; Szełeg, E.; Janeczek, J.; Nejbert, K. Granitic pegmatites of the Polish part of the Sudetes (NE Bohemian massif, SW Poland). In Fieldtrip Guidebook, Proceedings of the 7th International Symposium on Granitic Pegmatites, Ksią̇̇, Poland, 17-19 June 2015; PEG2015: Książ, Poland, 2015; pp. 73-103.

5. Oliver, G.J.H.; Corfu, F.; Krogh, T.E. U-Pb ages from SW Poland: Evidence for a Caledonian suture zone between Baltica and Gondwana. J. Geol. Soc. Lond. 1993, 150, 355-369. [CrossRef]

6. Van Breemen, O.; Bowes, D.R.; Aftalion, M.; Żelaźniewicz, A. Devonian tectonothermal activity in the Sowie Góry gneissic block, Sudetes, southwestern Poland: Evidence from Rb-Sr and U-Pb isotopic studies. J. Pol. Geol. Soc. 1988, 58, 3-10.

7. Timmermann, H.; Parrish, R.R.; Noble, S.R.; Kryza, R. New U-Pb monazite and zircon data from the Sudetes Mountains in SW Poland: Evidence for a single-cycle Variscan orogeny. J. Geol. Soc. Lond. 2000, 157, 265-268. [CrossRef]

8. Turniak, K.; Pieczka, A.; Kennedy, A.K.; Szełęg, E.; Ilnicki, S.; Nejbert, K.; Szuszkiewicz, A. Crystallisation age of the Julianna pegmatite system (Góry Sowie Block, NE margin of the Bohemian massif): Evidence from U-Th-Pb SHRIMP monazite and CHIME uraninite studies. In Book of Abstracts, Proceedings of the 7th International Symposium on Granitic Pegmatites, Książ, Poland, 17-19 June 2015; PEG2015: Książ, Poland, 2015; pp. 111-112.

9. Pieczka, A. A rare mineral-bearing pegmatite from the Szklary serpentynite massif, the Fore-Sudetic Block, SW Poland. Geol. Stud. 2000, 33, 23-31.

10. Pieczka, A. Primary Nb-Ta minerals in the Szklary pegmatite, Poland: New insights into controls of crystal chemistry and crystallization sequences. Am. Mineral. 2010, 95, 1478-1492. [CrossRef] 
11. Pieczka, A.; Grew, E.S.; Groat, L.A.; Evans, R.J. Holtite and dumortierite from the Szklary pegmatite, Lower Silesia, Poland. Mineral. Mag. 2011, 75, 303-315. [CrossRef]

12. Pieczka, A.; Evans, R.J.; Grew, E.S.; Groat, L.A.; Ma, C.; Rossman, G.R. The dumortierite supergroup. II. Three new minerals from the Szklary pegmatite, SW Poland: Nioboholtite, $\left(\mathrm{Nb}_{0.6} \square_{0.4}\right) \mathrm{Al}_{6} \mathrm{BSi}_{3} \mathrm{O}_{18}$, titanoholtite, $\left(\mathrm{Ti}_{0.75} \square_{0.25}\right) \mathrm{Al}_{6} \mathrm{BSi}_{3} \mathrm{O}_{18}$, and szklaryite, $\square \mathrm{Al}_{6} \mathrm{BAs}^{3+}{ }_{3} \mathrm{O}_{15}$. Mineral. Mag. 2013, 77, 2841-2856. [CrossRef]

13. Tait, K.; Ball, N.A.; Hawthorne, F.C. Pieczkaite, ideally $\mathrm{Mn}_{5}\left(\mathrm{PO}_{4}\right)_{3} \mathrm{Cl}$, a new apatite-supergroup mineral from Cross Lake, Manitoba, Canada: Description and crystal structure. Am. Mineral. 2015, 100, 1047-1052. [CrossRef]

14. Mandarino, J.A. The Gladstone-Dale relationship. Part III. Some general applications. Can. Mineral. 1979, 17, 71-76.

15. Mandarino, J.A. The Gladstone-Dale relationship. Part IV. The compatibility concept and its application. Can. Mineral. 1981, 19, 441-450.

16. Pouchou, J.-L.; Pichoir, F. Quantitative analysis of homogeneous or stratified microvolumes applying the model "PAP". In Electron Probe Quantitation; Heinrich, K.F.J., Newbury, D.E., Eds.; Plenum Press: New York, NY, USA, 1991; pp. 31-75.

17. Bruker AXS Inc. APEX 3. In Bruker Advanced X-ray Solution; Bruker AXS Inc.: Madison, WI, USA, 2004.

18. Biagioni, C.; Bosi, F.; Hålenius, U.; Pasero, M. The crystal structure of turneaureite, $\mathrm{Ca}_{5}\left(\mathrm{AsO}_{4}\right)_{3} \mathrm{Cl}$, the arsenate analog of chlorapatite, and its relationships with the arsenate apatites johnbaumite and svabite. Am. Mineral. 2017, 102, 1981-1986. [CrossRef]

19. Sheldrick, G.M. Crystal structure refinement with SHELXL. Acta Crystallogr. 2015, C71, 3-8.

20. Wilson, A.J.C. Volume C: Mathematical, Physical and Chemical Tables. In International Tables for Crystallography; Kluwer Academic: Dordrecth, The Netherlands, 1992.

21. Brese, N.E.; O'Keeffe, M. Bond-valence parameters for solids. Acta Crystallogr. 1991, B47, 192-197. [CrossRef]

22. Kraus, W.; Nolze, G. POWDER CELL-A program for the representation and manipulation of crystal structures and calculation of the resulting X-ray powder patterns. J. Appl. Crystallogr. 1996, 29, 301-303. [CrossRef]

23. Hughes, J.M.; Rakovan, J. The crystal structure of apatite, $\mathrm{Ca}_{5}\left(\mathrm{PO}_{4}\right)_{3}(\mathrm{~F}, \mathrm{OH}, \mathrm{Cl})$. In Phosphates: Geochemical, Geobiological and Materials Importance; Kohn, M.L., Rakovan, J., Hughes, J.M., Eds.; Mineralogical Society of America: Chantilly, VA, USA, 2002.

24. Shannon, R.D. Revised effective ionic radii and systematic studies of interatomic distances in halides and chalcogenides. Acta Crystallogr. 1976, A32, 751-767. [CrossRef]

25. Hughes, J.M.; Cameron, M.; Crowley, K.D. Structural variations in natural F, OH, and Cl apatites. Am. Mineral. 1989, 74, 870-876.

26. Hughes, J.M.; Cameron, M.; Crowley, K.D. Crystal structures of natural ternary apatites: Solid solution in the $\mathrm{Ca}_{5}\left(\mathrm{PO}_{4}\right)_{3} \mathrm{X}(\mathrm{X}=\mathrm{F}, \mathrm{OH}, \mathrm{Cl})$ system. Am. Mineral. 1990, 75, 295-304.

27. Suitch, P.R.; Lacout, J.L.; Hewat, A.W.; Young, R.A. The structural location and role of $\mathrm{Mn}^{2+}$ partially substituted for $\mathrm{Ca}^{2+}$ in fluorapatite. Acta Crystallogr. 1985, B41, 173-179. [CrossRef]

28. Hughes, J.M.; Ertl, A.; Bernhardt, H.J.; Rossman, G.R.; Rakovan, J. Mn-rich fluorapatite from Austria: Crystal structure, chemical analysis and spectroscopic investigations. Am. Mineral. 2004, 89, 629-632. [CrossRef]

29. Strunz, H.; Nickel, E.H. Strunz Mineralogical Tables, 9th ed.; Schweizerbart'sche Verlagsbuchhandlung: Stuttgart, Germany, 2001.

30. Gaines, R.V.; Skinner, H.C.; Foord, E.E.; Mason, B.; Rosenzweig, A. Dana's New Mineralogy, 9th ed.; John Wiley \& Sons, Inc.: Hoboken, NJ, USA, 1997.

31. Pasero, M.; Kampf, A.R.; Ferraris, C.; Pekov, I.V.; Rakovan, J.; White, T.J. Nomenclature of the apatite supergroup minerals. Eur. J. Mineral. 2010, 22, 163-179. [CrossRef]

32. Černý, P.; Fryer, B.J.; Chapman, R. Apatite from granitic pegmatite exocontact in Moldanubian serpentinites. J. Czech Geol. Soc. 2001, 46, 15-20.

33. Deschamps, F.; Godard, M.; Guillot, S.; Hattori, K. Geochemistry of subduction zone serpentynites: A review. Lithos 2013, 178, 96-127. [CrossRef]

(C) 2018 by the authors. Licensee MDPI, Basel, Switzerland. This article is an open access article distributed under the terms and conditions of the Creative Commons Attribution (CC BY) license (http://creativecommons.org/licenses/by/4.0/). 